Larsen, H. C. 1986: Project KANUMAS - proposal for a regional marine seismic survey around Greenland: geophysical description. Unpubl. intern. GGU rep., $58 \mathrm{pp}$.

Larsen, H. C. \& Marcussen, C. 1985: Orientering om planlagte oliegeologiske basisundersøgelser i Østgrønland nord for Jameson Land. Unpubl. intern. GGU rep., $10 \mathrm{pp.}$

Perch-Nielsen, K., Birkenmajer, K., Birkelund, T. \& Aellen, M. 1974: Revision of Triassic stratigraphy of the Scoresby Land and Jameson Land region, East Greenland. Bull. Grønlands geol. Unders. 109, $51 \mathrm{pp}$.

Piasecki, S. 1986: Initial evaluation of the hydrocarbon potential of central East Greenland, $72^{\circ}-75^{\circ} \mathrm{N}$. Unpubl. intern. GGU rep., 34 pp.

Piasecki, S. \& Marcussen, C. 1986: Oil geological studies in central East Greenland. Rapp. Grønlands geol. Unders. 130, 95-102.

Surlyk, F. 1977: Stratigraphy, tectonics and palaeogeography of the Jurassic sediments of the areas north of Kong Oscars Fjord, East Greenland. Bull. Grønlands geol. Unders. 123, 56 pp.

Surlyk, F. 1983: Source rock sampling, stratigraphical and sedimentological studies in the Upper Palaeozoic of the Jameson Land basin, East Greenland. Rapp. Grønlands geol. Unders. 115, 88-93.

Surlyk, F., Hurst, J. M., Marcussen, C., Piasecki, S., Rolle, F., Scholle, P. A., Stemmerik, L. \& Thomsen, E. 1984a: Oil geological studies in the Jameson Land basin, East Greenland. Rapp. Grønlands geol. Unders. 120, 85-90.

Surlyk, F., Piasecki, S., Rolle, F., Stemmerik, L., Thomsen, E. \& Wrang, P. 1984b: The Permian basin of East Greenland. In Spencer, A. M. et al. (edit.) Petroleum geology of the north European margin, 303-315. Graham \& Trotman Ltd for the Norwegian Petroleum Society.

Surlyk, F., Piasecki, S. \& Rolle, F. 1986a: Initiation of petroleum exploration in Jameson Land, East Greenland. Rapp. Grønlands geol. Unders. 128, 103-121.

Surlyk, F., Hurst, J. M., Piasecki, S., Rolle, F., Scholle, P. A., Stemmerik, L. \& Thomsen, E. 1986b: The Permian of the western margin of the Greenland Sea - a future exploration target. In Halbouty, M. T. (edit.) Future petroleum provinces of the world. Mem. Am. Ass. Petrol. Geol. 40, 629-659. Witzig, E. 1954: Stratigraphische und tektonische Beobachtungen in der Mesters Vig-Region (Scoresby Land, Nordostgrönland). Meddr Grønland 72(5), $26 \mathrm{pp}$.

H. O.\& J. B. $-K$, Institut for Almen Geologi, $\emptyset$ ster Voldgade 10 $D K-1350$ Copenhagen $K$, Denmark.

\title{
An ice-sampling programme in the Thule area, North Greenland
}

\author{
Niels Reeh and Henrik Højmark Thomsen
}

A glaciological programme was carried out as part of the NORDQUA 86 expedition to the Thule area, North Greenland, from 7 to 24 August 1986.

The expedition included researchers from the five Nordic countries and Great Britain and was organised by the Geological Museum, Copenhagen (Funder, in press). The expedition had a Quaternary geological programme, as well as a glaciological programme dealing with the climatic history and ice-sheet dynamics before and during the last Ice Age in the area.

The glaciological programme involved collection of ice samples to be analysed for $\delta^{18} \mathrm{O}$. 


\section{Recent stable isotope studies on the Greenland ice-sheet margin}

Ice, snow and water samples were collected from the surface of the ablation zone of the Inland Ice in the Jakobshavn area, West Greenland, and in Warming Land, North Greenland (Reeh \& Thomsen, 1986a, b; Reeh et al., in press). The samples were analysed for $\delta^{18} \mathrm{O}$. The results obtained so far show that isotope studies of the ice-sheet margin are useful for glacier hydrology, ice dynamics, palaeoclimate and for distinguishing different kinds of ice.

The results from the Jakobshavn area show that points in the accumulation and ablation zones of the ice sheet with the same observed $\delta^{18} \mathrm{O}$ value can be linked and used to locate the start and end points of particle paths (flow lines). Samples collected at the margin of Jakobshavn Isbræ suggest that isotope studies can contribute to a better understanding of icestream dynamics. Samples collected in profiles transverse to the ice margin in both the Jakobshavn area and Warming Land show the Holocene/Wisconsinian transition as a large abrupt $\delta$-shift between 470 and more than $850 \mathrm{~m}$ from the ice edge. The magnitude of the $\delta$ shift was about $8 \%$ and $12 \%$ in the West and North Greenland records, respectively.

The results of stable isotope investigations at the ice-sheet margin could be useful for studying local glaciological and regional palaeoclimatic conditions.

\section{Glaciological setting and programme in Thule}

The main efforts were concentrated at two ice-margin locations, the Tuto Ramp and the Nuna Ramp (fig. 1).

The Tuto Ramp is fed by ice accumulating on a local dome located about $7.5 \mathrm{~km}$ east of the ice margin. The dome is connected to the main Greenland ice sheet by a saddle and a long undulating ridge and thus is dynamically independent of the main ice sheet. The present ice-surface topography suggests that the ablation zone at the Tuto Ramp is fed by locally deposited ice and that ice presently deposited on the main ice sheet cannot reach the Tuto Ramp area. This must have been the case as long as the Tuto 'Dome' has been separated from the main ice sheet by a saddle.

The Nuna Ramp, on the contrary, forms part of the ablation zone of the main ice sheet. The flowlines terminating at the ramp have their origin in the centre of the ice sheet and run north and later west along the main ice divide. Thus the ice of the two different ice margin locations should originate from very different locations provided the present flow pattern has remained essentially unchanged during a long period of time. The main purpose of the glaciological programme was to throw light on these conditions.

\section{Sampling programme}

More than 450 samples of water, ice and snow were collected from seven different locations (fig. 1).

Ice, water and snow samples were collected along two profiles, 885 and $1001 \mathrm{~m}$ long, transverse to the ice margin at Tuto Ramp and Nuna Ramp, respectively. At two locations (elevation $850 \mathrm{~m}$ and $1010 \mathrm{~m}$ ) on the local Tuto dome, snow samples were collected from snow pits in the accumulation zone. Further ice samples were collected from two profiles 75 
Fig. 1. Location map of the Thule area. Sample locations are marked with circles.

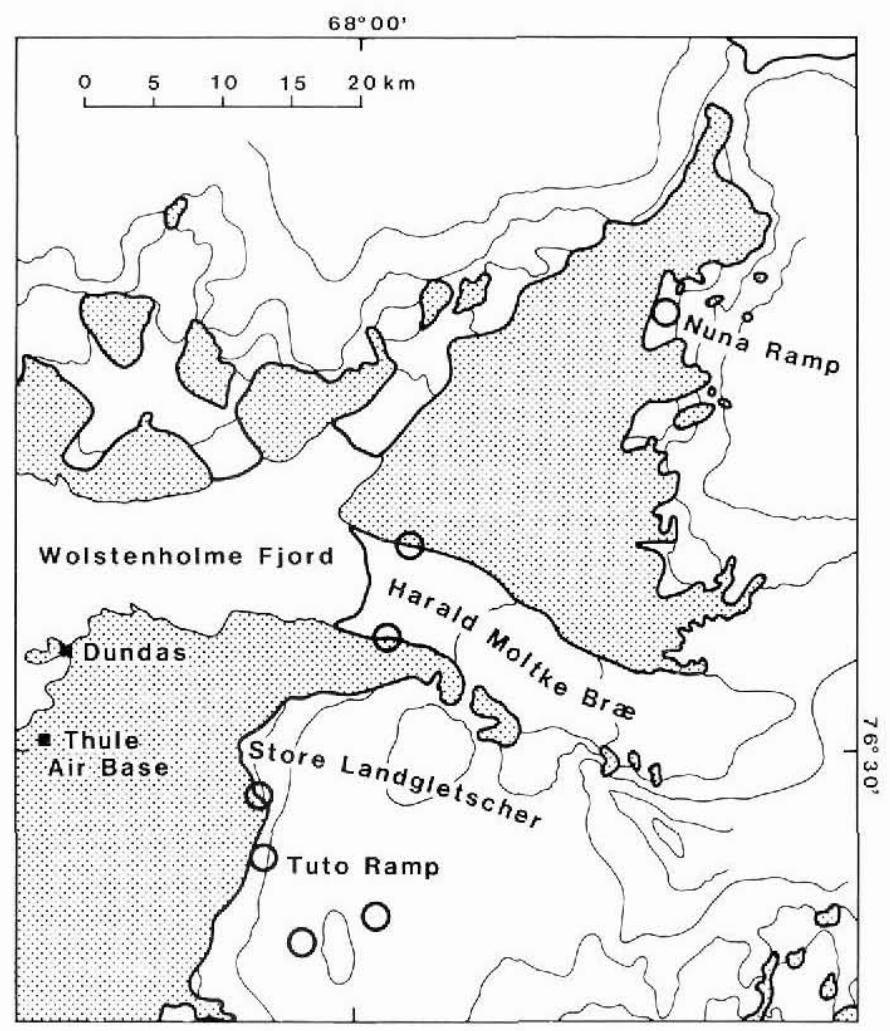

$\mathrm{m}$ and $110 \mathrm{~m}$ long, tranverse to the ice margin at the northern and southern part of the calfice producing glacier, Harald Moltke Bræ, for comparison with results from Jakobshavn Isbræ in the Disko Bugt area. Some 60 ice samples were collected from the bottom to the top of an $11 \mathrm{~m}$ high ice cliff at the southern part of Store Landgletscher. At the same location, ice samples were collected along a $500 \mathrm{~m}$ profile at the ice surface leading to the cliff.

The samples collected will be analysed for $\delta^{18} \mathrm{O}$ at the Geophysical Institute, University of Copenhagen during the winter of 1986-1987.

Acknowledgements. The authors thank the participants in the NORDQUA 86 expedition for taking part in the sampling programme.

\section{References}

Funder, S. in press: NORDQUA 86, Grønland. Nordic cooperation over Greenland's ice-age. Boreas.

Reeh, N. \& Thomsen, H. H. 1986a: Stable isotope studies on the Greenland ice-sheet margin. Rapp.

Gronlands geol. Unders. 130, 108-114.

Rech, N. \& Thomsen, H. H. 1986b: Model for simulering af ilt-isotop variationen i smeltevandsafstrømningen fra Indlandsisens rand ved Pâkitsup Akuliarusersua, Jakobshavn. Grønlands geol. Unders., Gletscher-hydrol. Meddr 86/1, 34 pp. 
Reeh, N., Thomsen, H. H. \& Clausen, H. B. in press: The Greenland ice-sheet margin - a mine of ice for palaeo-environmental studies. Palaeogeogr., Palaeoclim., Palaeoecol.

N. R.,

Polar Continental Shelf Project, Energy, Mines and Resources Canada,

Ottawa, Ontario

Canada, K1A OE4.

\title{
Continued glaciological work north-east of Jakobshavn, West Greenland
}

\author{
Henrik Højmark Thomsen
}

Glaciological investigations were carried out on the Inland Ice north-east of Jakobshavn. The work is part of the hydropower investigations at Pâkitsoq on a drainage basin proposed for a local hydropower project. The work was started in 1982, when stakes for measuring mass balance were drilled into the ice. So far the investigations have included mass balance measurements, photogrammetric and satellite mapping, ice-thickness mapping, stable isotope studies, simulation of runoff and ice dynamics (Reeh, 1983; Thomsen, 1983, 1984, 1985; Braithwaite \& Thomsen, 1984; Thomsen \& Braithwaite, 1985; Thomsen \& Reeh, 1986; Reeh \& Thomsen, 1986a; Thorning et al., 1986).

\section{Fieldwork 1986}

Mass balance measurements 1985/1986. The stakes were visited by helicopter on 13 May, 31 July and 25 August (fig. 1). Six new stakes (stakes 2, 21, 22, 23, 24, 25) were established in May. The six new stakes are all located near the ice margin ending in lake 187, and are represented by stake 2 in fig. 1 .

The winter snow cover on the ice was very patchy and confined mainly to drifts in gullies and crevasses up to an elevation about $600 \mathrm{~m}$ a.s.l., whereas it was continuous at higher elevations. The transient balance for the winter period was measured in snow pits, and by depth soundings at the stakes. As there were no signs of heavy melting during the winter, the observed distribution of snow cover is probably due to wind drifting. This year's measurements show a higher snow accumulation in the area compared to the previous two years. The transient annual balances are shown in fig. 2. The 1986 summer ablation is small compared to earlier years. This is mainly due to very limited ablation from May to August. From fig. 2, it can be seen that the annual equilibrium line was between 1000 and $1100 \mathrm{~m}$ a.s.l.

Drainage conditions on the Inland Ice. Surface-drainage conditions were studied by reconnaissance on foot and by helicopter. The reconnaissance was confined to areas where large moulins could be seen on recent aerial photographs. 